\title{
KEBIJAKAN HUKUM PIDANA DALAM MEMBERIKAN PERLINDUNGAN HUKUM TERHADAP GURU DALAM HAL KEDISPLINAN
}

\author{
Wijiatmo \\ Email : maswiedshohibku@yahoo.co.id \\ Mahasiswa Magister Ilmu Hukum Universitas Sebelas Maret Surakarta \\ Supanto \\ Email : supanto07@yahoo.com \\ Dosen Fakultas Hukum Universitas Sebelas Maret Surakarta
}

\begin{abstract}
This writing aims to determine how the criminal law policy in providing legal protection of teachers, especially those involved in teaching discipline to students. This Legal Research or Legal Research uses a normative study by understanding and analyzing the source of regulations concerning the protection of teachers and children. The results of this study we can understand that according to the Criminal Code of action of teachers in educating students, especially by upholding the discipline that caused a certain violence is not an act that can be punished for reasons of Tuchrecht as the reason for the criminal eraser. While the protection of teachers when doing acts of violence against the students is regulated by Law Number 14 Year 2005 jo Law Number 20 Year 2003 on National Education System jo Government Regulation Number 74 of 2008 Also confirmed by the Jurisprudence of the Supreme Court and the Regulation of the Minister of Education and Culture No. 10 Year 2017 on Protection for Educators and Education Personnel.
\end{abstract}

Keywords: Criminal law policy; legal protection; teacher.

\begin{abstract}
Abstrak
Penulisan ini bertujuan untuk mengetahui bagaimanakah kebijakan hukum pidana dalam memberikan perlindungan hukum terhadap guru khususnya yang menyangkut dalam mengajarkan kedisiplinan pada siswa. Penelitian Hukum atau Legal Research ini menggunakan kajian saecara normative dengan cara memahami dan menganalisis dari sumber peraturan yang menyangkut tentang perlindungan guru dan anak. Hasil dari penelitian ini dapat kita pahami bahwa menurut KUH Pidana tindakan guru dalam mendidik siswa khususnya dengan menegakkan kedisiplinan yang menga- kibatkan adanya kekerasan tertentu bukan merupakan tindakan yang dapat dipidana karena alasan Tuchrecht sebagai alasan penghapus pidanaa. Sedangkan perlindungan guru apabila melakukan tindakan kekerasan terhadap murid diatur dengan Undang-Undang Nomor 14 Tahun 2005 jo Undang-Undang Nomor 20 Tahun 2003 tentang Sistem Pendidikan Nasional jo Peraturan Pemerintah Nomor 74 tahun 2008 Juga dipertegas dengan Yurisprudensi Mahkamah Agung dan Peraturan Menteri Pendidikan dan Kebudayaan Nomor 10 Tahun 2017 tentang Perlindungan bagi pendidik dan Tenaga Kependidikan.
\end{abstract}

Kata kunci : Kebijakan hukum pidana; perlindungan hukum; guru. 


\section{A. Pendahuluan}

Tujuan Pendidikan Nasional adalah mencerdaskan kehidupan bangsa dan mengembangkan manusia Indoensia seutuhnya, yaitu manusia yang beriman dan bertaqwa terhadap Tuhan Yang Maha Esa dan berbudi pekerti luhur, memiliki pengetahuan dan keterampilan, kesehatan jasmani dan rohani, kepribadian yang mantap dan mandiri serta rasa tanggung jawab kemasyarakatan dan kebangsaan.

Pada intinya pendidikan itu bertujuan untuk membentuk karakter seseorang yang beriman dan bertakwa kepada Tuhan Yang Maha Esa. Akan tetapi disini pendidikan hanya menekankan pada intelektual saja, dengan bukti bahwa adanya UN sebagai tolak ukur keberhasilan pendidikan tanpa melihat proses pembentukan karakter dan budi pekerti anak.

Posisi seorang guru sebagai tenaga pendidik seringkali berada pada posisi yang dilematis, antara tuntutan profesi dan perlakukan masyarakat. Di satu sisi, mereka dituntut untuk mampu mengantarkan peserta didik mencapai tujuan pendidikan. Namun di sisi lain, tatkala para guru berupaya untuk menegakkan kedisplinan, mereka dihadang oleh UU Perlindungan Anak dan Komisi Perlindungan Anak Indonesia. Jika mereka gagal menegakkan kedisiplinan peserta didiknya dan gagal mengantarkan peserta didik pada pencapaian tujuan pendidikan, sebagai pendidik guru acapkali dituding menjadi biangnya atas kegagalan tersebut. Persoalan yang paling krusial dihadapi oleh seorang guru adalah tatkala mereka harus memberikan hukuman kepada peserta didik yang melanggar tata tertib dan aturan sekolah dalam rangka menegakkan kedisiplinan, acapkali orang tua dan masyarakat menilainya sebagai tindakan melanggar hak asasi manusia atau melanggar UU Perlindungan Anak. Mereka dengan mudahnya melaporkan tindakan guru tersebut kepada penegak hukum (baca: polisi atau KPAI). Akibatnya, dalam menjalankan tugas profesinya guru seringkali berada pada posisi dilematis dan bahkan rentan untuk dikriminalisasi.

Untuk itu pemerintah perlu segera menerbitkan peraturan pelaksanaan dari pasal 39 ayat (1) UUGD di atas, yang secara teknis mengatur perlindungan hukum terhadap guru dalam menjalankan tugas profesinya. Peraturan pelaksanaan tersebut harus secara tegas mengatur mengenai apa saja yang boleh dilakukan dan apa saja yang tidak boleh (dilarang) dilakukan oleh seorang guru terhadap peserta didiknya dalam memberikan sanksi disiplin. Tujuannya, agar di satu sisi guru dapat bekerja profesional tanpa takut dikriminalisasi, dan sebaliknya, melalui peraturan tersebut penegak hukum dan masyarakat juga mempunyai standar atau pedoman yang sama untuk menilai apakah tindakan guru kepada peserta didik dalam memberikan sanksi itu sesuai aturan atau melanggar aturan. Sanksi disiplin itu tentu saja harus bersifat mendidik.

Di media sosial sering ramai diberitakan seorang guru yang diadukan oleh orang tua murid karena dianggap telah kekerasan fisik dan psikis terhadap muridnya, juga berita tentang guru yang telah dianiaya dan dikeroyok oleh orang tua murid. Guru dilaporkan melanggar hak perlindungan anak ketika ketika memberikan sanksi pelanggaran displin terhadap siswa, seperti dijewer, dipukul, dibentak, disuruh lari mengililingi halaman sekolah, disuruh push up beberapa kali, disuruh menghormat bendera dalam kondisi cuaca panassampai akhir pelajaran, membersihkan toilet, dan sebagainya. Jenis-jenis hukuman disiplin seperti yang masa lampau dianggap biasa atau lumrah dalam dunia pendidikan, sat ini dinilai tidak lagi mendidik dan bahkan dianggap melanggar Undang-undang Perlindungan Anak. Sanksi disiplin seperti itu, 
dulu tidak dianggap sebagai pelanggaran hukum, tetapi kini guru harus semakin hati-hati dalam memberikan hukuman disiplin kepada siswa. Hukuman disiplin yang diberikan kepada siswa harus berpedoman kepada tata tertib sekolah dan Undang-undang Nomor 35 Tahun 2014 tentang Perubahan atas Undang-Undang Nomor 23 Tahun 2002 tentang Perlidungan Anak. Berdasarkan uraian di atas, maka akan dibahas mengenai Kebijakan hukum pidana dalam memberikan perlindungan hukum terhadap guru dalam hal kedisplinan.

\section{B. MetodePenelitian}

Jenis Penelitian yang diaplikasikan oleh Penulis dalam Penellitian ini adalah Penelitian Hukum atau Legal Research.Legal Research berperan penting dalam kerangka pengembangan Ilmu Hukum dan mengungkan faktor penyebab timbulnya masalah-masalah yang berkaitan dengan hukum. Dari hasil penelitian tersebut, dapat diketahu faktor penyebab dan bagaimana pemecahan dari masalah yang diteliti tersebut. Peter Mahmud Marzuki mengemukakan bahwa penelitian hukum adalah suatu proses untuk menemukan aturan hukum maupun doktrin-doktrin hukum guna menjawab isu hukum yang dihadapi.

Pada dasarnya, hasil dari suatu penelitian normative adalah argumentasi hukum. Oleh karena itu, penalaran hukum (legal reasoning) dalam penelitian hukum normatif adalah penting. Melalui penalaran hukum hukum diharapkan langkah-langah kajian hukum dapat sesuai dengan maksud dan tujuan penelitian. Sesuai dengan pandangan Lord Lloyd O. Hamstead dan MDA Freeman, bahwa ilmu hukum menyangkut studi terhadap pertanyaan teorikal tentang hakikat hukum dan sistem hukum, tentang hubungan hukum dengan keadilan dan moralitas serta tentang hakekat sosial dari hukum.

\section{Hasil Penelitian dan Pembahasan}

Tindakan guru dalam menjalankan profesinya yakni mendidik siswa dengan cara mendisiplinkan siswa dari perbuatan yang keluar dari nilai pendidikan yang diajarkan, bukanlah suatu perbuatan pidana, baik berupa pelanggaran ataupun kejahatan. Sementara itu guru saat mendidik siswa khususnya dalam rangka mengajarkan sebuah kedisiplinan, dihadapkan pada kenyataan bahwa tindakannya itu ( kedisiplinan ) yang dinilai sebagai kekerasan yang berakhir di pengadilan atau penjara.

Pasal-pasal yang dikenakan terhadap tindakan guru dalam mendidik kedisiplin diantaranya, adalah :

1. Pasal 58 Undang-undang No. 39 tahun 1999 tentang HAM secara spesifik memberikan perlindungan terhadap kekerasan terhadap anak "setiap anak berhak untuk mendapatkan perlindungan hukum dari segala bentuk kekerasan fisik atau mental, penelantaran, perlakuan buruk, dan pelecehan seksual selam dalam pengasuhan orang tuanya atau walinya, atau pihak lain manapun yang bertanggung jawab atas pengasuhan anak tersebut."

2. Pasal 33 Undang-undang no. 23 tahun 2002 pasal 3 adalah untuk menjamin terpenuhinya hak-hak anak agar dapat hidup, tumbuh, berkembang, dan berpartisipasi secara optimal sesuai dengan harkat dan martabat kemanusiaan, serta mendapat perlindungan dari 
kekerasan dan diskriminasi, demi terwujudnya anak Indonesia yang berkualitas, berakhlak mulia, dan sejahtera.

3. Pasal 9 ayat 1a Undang Undang No.35 Tahun 2014 mengatakan bahwa "setiap anak berhak mendapatkan perlindungan di satuan pendidikan dari kejahatan seksual dan kekerasan yang dilakukan oleh pendidik, tenaga kependidikan, sesama peserta didik, dan/atau pihak lain."

4. Pasal 54 ayat 1 menyebutkan bahwa "anak di dalam dan di lingkungan satuan pendidikan wajib mendapatkan perlindungan dan tindak kekerasan fisik, psikis, kejahatan seksual, dan kejahatan lainnya yang dilakukan oleh pendidik, tenaga kependidikan, sesama peserta didik, dan/atau pihak lain.

5. Pasal 1 ayat 15 a mendefinisikan bahwa "kekerasan adalah setiap perbuatan terhadap anak yang berakibat timbulnya kesengsaraan atau penderitaan secara fisik, psikis, seksual, dan/atau penelantaran, termasuk ancaman untuk melakukan perbuatan, pemaksaan, atau perampasan kemerdekaan secara melawan hukum.”

Pandangan Islam hukuman merupakan sebuah pendidikan . Hukuman yang dimaksud bukanlah hukuman dengan niat untuk balas dendam maupun emosional. Selain hukuman dilakukan dengan tujuan pendidikan hukuman yang berikan juga bertahap, menurut Dr. Muhammad Nur Abdul Hafizh Suwaid tahap pertama dalam hukuman adalah memperlihatkan cambuk kepada anak, maknanya adalah ancaman jika tetap mengulangi kesalahan yang sama, kedua adalah menjewer daun telinga, tahap ini bermaksud mengenalkan resiko kepada anak yang telah melakukan kesalahan, ketiga adalah memukul anak. Pada tahap hukuman memukul Islam mengatur bahwa pukulan tidak dilakukan sembarangan namun memiliki beberapa aturan diantaranya: memukul dimulai pada usia 10 tahun; jumlah pukulan tidak boleh lebih dari sepuluh kali, pendapat lain menyatakan pukulan maksimal adalah tiga kali; memperhatikan alat dan cara memukul, serta tempat yang dipukul; tidak boleh memukul disertai amarah; berhenti memukul apabila anak menyebut nama Allah.

Semangat pendidikan nasional dan pandangan Islam terlihat bertentangan dengan hukum yang melindungi anak. Hal ini tentu menimbulkan kebuntuan bagi para guru dan seluruh civitas akademik dari tingkat satuan pendidikan hingga kementerian. Bahkan, pernyataan Mendikbud yang dikutip dari BBC.com yang mengatakan bahwa "sanksi fisik dapat ditoleransi" menuai banyak protes.

Jawaban dari kebuntuan ini sebenarnya sangat sederhana secara konsep, yaitu mengembalikan kepada tujuan pendidikan. Pendidikan memiliki tujuan yang jelas sebagaimana dipaparkan di atas, untuk mencapai tujuan tersebut tentu para ahli dalam pendidikan mengetahui, sehingga dibuatkan kurikulum dan seluruh perangkat pendukungnya. Jika memang dengan melaksanakan hukuman fisik mampu mencapai tujuan pendidikan kenapa tidak dilakukan. Sedangkan HAM dan undang-undang perlindungan anak memiliki tujuan untuk melindungi anak menjadi korban kekerasan mulai dari fisik, psikis hingga seksual. Apabila pendidikan dapat mencapai tujuannya yaitu mencetak manusia yang cerdas dan juga memiliki akhlak yang mulia, maka HAM dan anak-akan pun pasti akan terlindungi karena anak-anak akan memperoleh pendidikan dari orang-orang dan lingkungan yang baik.

Kemudian dari sudut pandang konteks undang-undang kekerasan yang dimaksud oleh undang-undang HAM dan pelindungan anak merupakan kekerasan dalam konteks kejahatan, sedangkan hukuman fisik dalam konteks pendidikan adalah hukuman yang dilandasi rasa 
kasih sayang, dalam rangka membangun karakter disiplin dan tanggungjawab. Kedua hal tersebut bisa saling sinergi dalam satu tujuan yaitu mencetak manusia cerdas yang memiliki akhlak mulia, untuk melindungi anak-anak dari tindak kejahatan dan kekerasan dari manusiamanusia yang tidak beriman, tidak cerdas dan tidak berakhlak mulia.

Berdasarkan yurisprudensi Mahkamah Agung (MA) yang dikutip dari website MA, Jumat (12/8/2016), guru tidak bisa dipidana saat menjalankan profesinya dan melakukan tindakan pendisiplinan terhadap siswa. Hal itu diputuskan saat mengadili guru dari Majalengka, Jawa Barat, SD Aop Saopudin (31). Kala itu, Aop mendisiplinkan empat siswanya yang berambut gondrong dengan mencukur rambut siswa tersebut pada Maret 2012. Salah seorang siswa tidak terima dan melabrak Aop dengan memukulnya. Aop juga dicukur balik. Meski sempat didemo para guru, polisi dan jaksa tetap melimpahkan kasus Aop ke pengadilan. Aop dikenakan pasal berlapis, yaitu :

1. Pasal 77 huruf a UU Perlindungan Anak tentang perbuatan diskriminasi terhadap anak.

Pasal itu berbunyi: Setiap orang yang dengan sengaja melakukan tindakan diskriminasi terhadap anak yang mengakibatkan anak mengalami kerugian, baik materiil maupun moril sehingga menghambat fungsi sosialnya dipidana dengan pidana penjara paling lama 5 tahun dan/atau denda paling banyak Rp 100 juta.

2. Pasal 80 ayat 1 UU Perlindungan Anak Pasal 335 ayat 1 kesatu KUHP tentang Perbuatan Tidak Menyenangkan.

Atas dakwaan itu, Aop dikenakan pasal percobaan oleh PN Majalengka dan Pengadilan Tinggi (PT) Bandung. Tapi oleh MA, hukuman itu dianulir dan menjatuhkan vonis bebas murni ke Aop. Putusan yang diketok pada 6 Mei 2014 itu diadili oleh ketua majelis hakim Dr Salman Luthan dengan anggota Dr Syarifuddin dan Dr Margono. Ketiganya membebaskan Aop karena sebagai guru Aop mempunyai tugas untuk mendisiplinkan siswa yang rambutnya sudah panjang/gondrong untuk menertibkan para siswa. Pertimbangannya adalah: "Apa yang dilakukan terdakwa adalah sudah menjadi tugasnya dan bukan merupakan suatu tindak pidana dan terdakwa tidak dapat dijatuhi pidana atas perbuatan/tindakannya tersebut karena bertujuan untuk mendidik agar menjadi murid yang baik dan berdisiplin.

Perlindungan terhadap profesi guru sendiri sudah diakui dalam PP Nomor 74 Tahun 2008. Dalam PP itu, guru adalah pendidik profesional dengan tugas utama mendidik, mengajar, membimbing, mengarahkan, melatih, menilai, dan mengevaluasi peserta didik pada pendidikan anak usia dini jalur pendidikan formal, pendidikan dasar, dan pendidikan menengah.

Dalam mendidik, mengajar, membimbing hingga mengeva luasi siswa, maka guru diberikan kebebasan akademik untuk melakukan metode-metode yang ada. Selain itu, guru juga tidak hanya berwenang memberikan penghargaan terhadap siswanya, tetapi juga memberikan punishment kepada siswanya tersebut. "Guru memiliki kebebasan memberikan sanksi kepada peserta didiknya yang melanggar norma agama, norma kesusilaan, norma kesopanan, peraturan tertulis maupun tidak tertulis yang ditetapkan guru, peraturan tingkat satuan pendidikan, dan peraturan perundang-undangan dalam proses pembelajaran yang berada di bawah kewenangannya," bunyi Pasal 39 ayat 1. Dalam ayat 2 disebutkan, sanksi tersebut dapat berupa teguran dan/atau peringatan, baik lisan maupun tulisan, serta hukuman yang bersifat mendidik sesuai dengan kaedah pendidikan, kode etik guru, dan peraturan perundang-undangan. "Guru berhak mendapat perlindungan dalam melaksanakan tugas 
dalam bentuk rasa aman dan jaminan keselamatan dari pemerintah, pemerintah daerah, satuan pendidikan, organisasi profesi guru, dan/atau masyarakat sesuai dengan kewenangan masing-masing," papar Pasal 40. Rasa aman dan jaminan keselamatan tersebut diperoleh guru melalui perlindungan hukum, profesi dan keselamatan dan kesehatan kerja. "Guru berhak mendapatkan perlindungan hukum dari tindak kekerasan, ancaman, perlakuan diskriminatif, intimidasi, atau perlakuan tidak adil dari pihak peserta didik, orang tua peserta didik, masyarakat, birokrasi, atau pihak lain," tegas Pasal 41.Kekerasan yang dijadikan dasar untuk membawa guru ke meja hijau menimbulkan beberapa pandangan. Sementara itu dalam beberapa isitlah di jelaskan sebagai berikut :

Menurut Kamus Bahasa Indonesia Kontemporer, kekerasan adalah perihal atau sifat keras, paksaan, perbuatan yang menyebabkan kerusakan fisik atau barangorang lain. Sedangkan menurut Kamus Webster mendefinisikan kekerasan sebagai penggunaan kekuatanfisik untuk melukai atau menganiaya, perlakuan atau prosedur yang kasar serta keras. Bertolak dari kedua istilah asing tersebut, maka istilah kebijakan hukum pidana dapat pula disebut dengan istilah politik hukum pidana. Dalam kepustakaan asing istilah politik hukum pidana ini sering dikenal dengan berbagai istilah, antara lain penal policy, criminal law policy atau staftrechtspolitiek.

Dengan demikian, kebijakan hukum pidana dapat diartikan dengan cara bertindak atau kebijakan dari negara (pemerintah) untuk menggunakan hukum pidana dalam mencapai tujuan tertentu, terutama dalam menanggulangi kejahatan. Memang diakui bahwa banyak cara maupun usaha yang dapat dilakukan oleh setiap negara (pemerintah) dalam menanggulangi kejahatan. Salah satu upaya untuk dapat menanggulangi kejahatan, diantaranya melalui suatu kebijakan hukum pidana atau politik hukum pidana.

Menurut Utretch, politik hukum menyelidiki perubahan-perubahan apa yang harus diadakan dalam hukum yang sekarang berlaku supaya sesuai dengan kenyataan sosial. Politik hukum membuat suatu Ius constituendum (hukum yang akan berlaku) dan berusaha agar Ius constituendum itu pada suatu hari berlaku sebagai Ius constitutum (hukum yang berlaku yang baru.

Politik hukum pidana diartikan juga sebagai kebijakan menyeleksi atau melakukan kriminalisasi dan dekriminalisasi terhadap suatu perbuatan. Disini tersangkut persoalan pilihan-pilihan terhadap suatu perbuatan yang dirumuskan sebagai tindak pidana atau bukan, serta menyeleksi diantara berbagai alternatif yang ada mengenai apa yang menjadi tujuan sistem hukum pidana pada masa mendatang. Oleh karena itu, dengan politik hukum pidana, negara diberikan kewenangan merumuskan atau menentukan suatu perbuatan yang dapat dikategorikan sebagai tindak pidana, dan kemudian dapat menggunakannya sebagai tindakan represif terhadap setiap orang yang melanggarnya. Inilah salah satu fungsi penting hukum pidana, yakni memberikan dasar legitimasi bagi tindakan yang represif negara terhadap seseorang atau kelompok orang yang melakukan perbuatan yang dirumuskan sebagai tindak pidana.

Penggunaan hukum pidana dalam mengatur masyarakat (lewat peraturan perundangundangan) pada hakekatnya merupakan bagian dari suatu langkah kebijakan (policy). Operasionalisasi kebijakan hukum pidana dengan sarana penal (pidana) dapat dilakukan melalui proses yang terdiri atas tiga tahap, yakni : a. Tahap formulasi (kebijakan legislatif) 
yaitu tahap perumusan/penyusunan hukum pidana; b. Tahap aplikasi (kebijakan yudikatif atau yudisial) yaitu tahap penerapan hukum pidana; c. Tahap eksekusi (kebijakan eksekutif atau administratif) yaitu tahap pelaksanaan hukum pidana.

\section{Simpulan}

Di dalam Undang Undang Perlindungan Anak (UUPA) pada dasarnya bertujuan baik, yaitu untuk melindungi anak dari tindak kekekerasan dan kesewenang-wenangan. Walau demikian, UUPA jangan sampai menyandera guru dalam mendidik anak didiknya melalui cara kedisiplinan. Setiap guru memiliki kehendak yang mulia, yakni agar setiap anak didiknya menjadi anak yang tertib,disiplin, cerdas, terampil, dan memiliki budi pekerti luhur.

Untuk itu, perlu adanya komunikasi yang baik antara orang tua siswa dengan pihak sekolah. Mensosialisasikan tata tertib sekolah, dan jika ada masalah yang menimpa anak didik di sekolah, mengedepankan penyelesaian secara damai atau kekeluargaan, dan sebisa mungkin dihindari penyelesaian secara hukum. Disamping itu, perlu adanya sosialisasi dan kesepahaman bersama antara orang tua, guru, dan siswanya itu sendiri terhadap peran, hak dan kewajiban masing-masing pihak berdasarkan UUPA.

\section{E. Saran}

Apabila ditemukan adanya laporan dari warga masyarakat, tugas polisi adalah menerima dan menindaklanjutinya. Dalam konteks laporan pengaduan kekerasan yang dilakukan oleh guru terhadap siswa, maka pihak kepolisian sebaiknya tidak langsung mendorong penyelesaian kasus pada ranah hukum, tetapi diselesaikan secara damai atau kekeluargaan.

Diharapkan Polisi menjadi mediator antara pihak pelapor dan terlapor, mencari jalan keluar yang paling baik yang bisa diterima oleh kedua belah pihak. Selain itu Penyelesaian secara hukum, akan menguras waktu, biaya, dan tenaga yang tidak sedikit, serta memberikan tekanan psikologis yang luar biasa utamanya terhadap pihak guru selaku terlapor. Penyelesaian secara hukum baru dirasa akan lebih efektif dikenakan bagi oknum guru yang terlibat kasus pencabulan atau tindakan kriminal lainnya untuk menimbulkan efek jera.

\section{F. Daftar Pustaka}

\section{Buku-buku :}

Bardan Nawawi Arief. 2003. Kapita Selekta Hukum Pidana. Bandung ; PT. Citra Aditya Bakti, Bandung.

Jan Remmelik.2003. Hukum Pidana : Komentar Atas Pasal-Pasal Terpenting Dalam Kitab Undang-Undang Hukum Belanda Dan Padanannya Dalam Kitab UndangUndang Hukum Pidana Indonesia. Jakarta ; Gramedia Pustaka Utama, Jakarta. 
Muladi. 2002. Demokratisasi, Hak Asasi Manusia Dan Reformasi Hukum Di Indonesia .Jakarta ; The Habibie Center.

Omar Seno Aji. 1984. Hukum (Acara) Pidana dalam Perspektif,.Jakarta: Erlangga.

Peter Mahmud Marzuki2009. Penelitian Hukum.Jakarta; Kencana.

Satjipto Raharjo.2000. Ilmu Hukum.Bandung; PT Citra Aditya Bakti.

Salim HS.2016. Penerapan Teori Hukum Pada Penelitian Tesis Dan Disertasi. Jakarta; Rajawali Pers.

Soerjono dan Sri Mamuji.2010. Penelitian Hukum Normatif Suatu Tinjauan Singkat. Jakarta ; Raja Grafindo Persada.

\section{Journal :}

Prof. Dr. Harun.2016."Perlindungan hukum profesi guru dalam perspektif hukum positip". Law and Justice. Vol.1 No.1 Oktober 2016

A Affandi.2017." Perlindungan anak diatur dalam Undang-Undang Nomor 35 Tahun 2014”. Jurnal Hukum Samudra Keadilan

E.Komara.2016.’Perlindungan Profesi Guru di Indonesia”.Jurnal Indonesia.Vol 1 (2) September 2016

Idawati.2014.'Tinjauan hukum terhadap perlindungan profesi guru dan anak didik".Jurnal Yustisia.Vol.1 Nomor 2 April 2014

Rusmilawati.2006.” Kebijakan hukum pidana terhadap penanggulangan tindak pidana di bidang pendidikan".Tesis 